\section{Detachment of crash helmets during motorcycle accidents}

Since 1973 motorcyclists have been required to wear a properly fastened, approved helmet when on the road. I report four cases in which such helmets became detached during an accident. In three cases fatal injuries resulted.

\section{Case reports}

Case 1-An 18 year old girl riding pillion on a motorcycle was thrown from the machine after a collision with an oncoming vehicle. Her helmet was seen to fly off before impact and was found later with intact strap and fixing bolts. She was unconscious from impact and suffered diffuse brain injury. She died five days later.

Case 2-A 21 year old racing motorcyclist crashed, and during the course of the accident I witnessed his helmet become detached from his head; fortunately he was not injured. The helmet was found with the strap correctly fastened and the fittings intact. Later examination of the rider with the helmet on showed that an apparently well fitting helmet could be easily lifted over the back of his head.

Cases 3 and 4-Two racing motorcyclists, aged 23 and 29, collided and were thrown from their machines. A film of the accident showed both helmets clearly coming off over the backs of the riders' heads. Both riders suffered fatal diffuse brain injuries.

\section{Comment}

Current motorcycle helmets are designed to reduce the severity of an injury by three mechanisms: firstly, by presenting a hard surface to prevent direct blows to the skull; secondly, by having a deformable polystyrene liner within the shell to dissipate deceleration forces; and, thirdly, by presenting a smooth surface to the road to prevent rotation of the head and neck. The helmet is strapped to the head with woven or leather straps that are fixed to the helmet by rivets. Failure of the shell, lining, or strap may lead to failure of the helmet itself, and uniformity of strength is controlled by the British Standards Institution. ${ }^{12}$

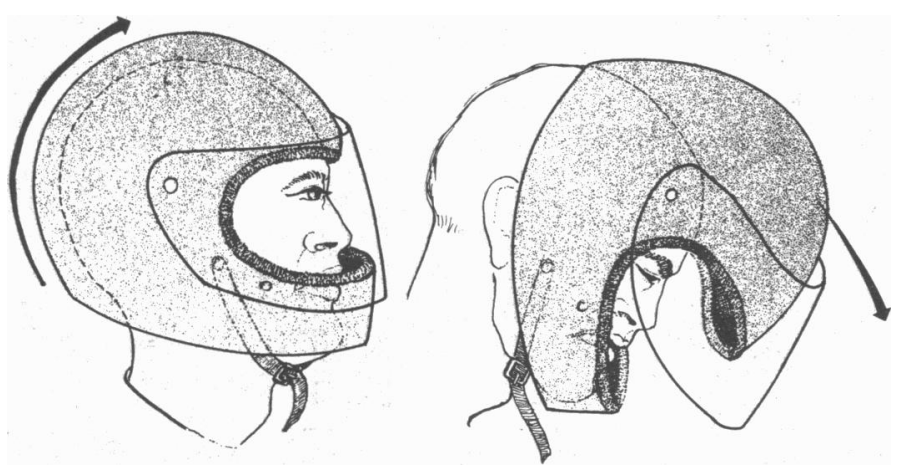

Manner in which helmet is detached at high speed, showing (left) normal position and (right) helmet pivoting forward on strap during accident.

All patients reported on here were wearing correctly fastened, full face helmets. Witnesses clearly saw the helmets fly off, and there was no question of the helmets having been removed after the patient had come to rest. There was no major damage to the shell or lining of the helmets recovered in the three fatal cases. One patient (case 2) was not injured, and the mechanism of the helmet coming off could be seen. The fixing bolts of the chin strap were near the base and the front of the helmet. This allowed the helmet to pivot forward on the strap, the pivot point lying anterior to the angle of the mandible (figure). This is more likely to happen if the rider has a flattened occiput. When I tested this on a random group of 14 motorcyclists with apparently well fitting, comfortable, and properly fastened helmets I was able to remove four of the helmets by pushing from behind.

Many motorcyclists may possibly be at risk of losing their helmets in accidents. Modification of the helmet by moving the strap mounting bolts further back and higher up the helmet would alter the pivot point, making it harder for the helmet to come off. Alternatively, the customer and dealer selling helmets should be aware of the prob- lem. A simple test of somebody pushing the helmet upwards from behind while it is on the customer's head should be performed. If the helmet can reach the vertex or beyond the customer should refuse to buy it and the dealer to sell it. The four patients described here were wearing four different makes of helmet, indicating that the problem is widespread. The manufacturer of the helmet in case 2 has already modified the product. It is to be hoped that other manufacturers will take a similarly responsible attitude.

I thank Mrs Irene Prentice for her artistic help.

British Standards Institution. Specification for protective helmets for vehicle users. BS5361. London: British Standards Institution, 1976.

${ }^{2}$ British Standards Institution. Specification for protective helmets for vehicle users (high protection). BS2495. London: British Standards Institution, 1977.

(Accepted 17 November 1983)

Central Middlesex Hospital, London NW10

$P$ G RICHARDS, FRCS, neurosurgical registrar

Correspondence to: Mr P G Richards, Gough-Cooper Department of Neurological Surgery, Institute of Neurology, London WC1.

\section{Role of anaerobes in cerebral abscesses of sinus origin}

Cerebral abscesses of sinus origin have been attributed to microaerophilic streptococci and treated with penicillin. ${ }^{1}$ We report three consecutive cases seen in our department, each of which grew a mixed aerobic and anaerobic microbacterial flora, including penicillin resistant organisms.

\section{Case reports}

Case 1-A 20 year old man developed right ethmoiditis associated with proptosis and periorbital cellulitis. Right ethmoidectomy and drainage of the frontal sinus were performed. During treatment with benzylpenicillin and chloramphenicol he developed left frontal sinusitis. On exploration the posterior frontal sinus wall was found to be deficient. Metronidazole was added to the regimen. The patient deteriorated and a right frontal lobe abscess was drained, yielding Streptococcus milleri Lancefield group C, Haemophilus aphrophilus, and Bacteroides melaninogenicus, resistant to penicillin. Further deterioration necessitated a partial right frontal lobectomy, from which he made a good recovery.

Case 2-A 15 year old boy with frontal sinusitis was treated with amoxycillin. He developed a right hemiparesis and focal fits. An extradural left frontal abscess and left pansinusitis were confirmed by computed tomography and evacuated. During treatment with benzylpenicillin and sulphadimidine the patient deteriorated and a left subdural abscess was aspirated. Anaerobic streptococci and Str milleri Lancefield group F were isolated from the abscess and pus fluoresced red under ultraviolet light, suggesting the presence of $B$ melaninogenicus. Metronidazole was added to the regimen and the patient made a full recovery.

Case 3-A 24 year old man with pansinusitis treated by oral penicillin was admitted with left sided focal fits and hemiparesis. Right subdural empyema and pansinusitis were confirmed by computed tomography and pus evacuated from these sites yielded Fusobacterium spp, anaerobic steptococci, and $H$ influenzae. The patient had begun benzylpenicillin, gentamicin, and metronidazole on admission and made a full recovery.

\section{Comment}

It is well recognised that cerebral abscesses of otitic aetiology frequently yield a mixed aerobic and anaerobic microbacterial flora, often including Bacteroides spp. In contrast, cerebral abscesses of sinusitic origin have been attributed primarily to "penicillin sensitive streptococci" and it has been asserted that chemotherapy should be aimed at these organisms. ${ }^{1}$

A recent study has shown that potentially pathogenic anaerobes are usually present in the normal paranasal sinus, with Peptostreptococcus spp and Bacteroides spp most commonly cultured. ${ }^{2}$ When purulent secretion is present the oxygen tension of the maxillary sinus is zero, favouring the proliferation of these organisms. Other studies have shown that similar anaerobes are frequently present in both acute and chronic maxillary sinusitis. ${ }^{3}$

In each of our cases a mixed aerobic and anaerobic flora was 
obtained, and in particular $B$ melaninogenicus was found in two. In a recent survey of complications after sinus infections in children, Brook et al also found pathogenic anaerobes in every instance and Bacteroides spp in five of the eight cases. ${ }^{4}$

Penicillin is active against most anaerobes but some strains of $B$ melaninogenicus and most strains of $B$ fragilis are resistant. In addition, both of these strains have the capability to produce penicillinase, thus protecting penicillin sensitive organisms.

Bacteroides and anaerobic cocci have a greater tendency to induce septic thrombophlebitis than aerobes, ${ }^{5}$ and their presence is therefore likely to favour complications. This emphasises the role of early, detailed, and accurate bacteriological investigation in each case. Distinction of anaerobes from microaerophilic streptococci may be difficult and gas-liquid chromatography for volatile fatty acids is particularly relevant.

We suggest that unless anaerobes can be specifically excluded all paranasal sinus infections failing to respond promptly or developing complications should be treated with metronidazole in addition to the normal therapeutic regimen.

We thank Mr P D M Ellis, Mr D Moffat, and Mr D Hardy for permission to report these cases and Dr R E Warren for help in preparing this report.

1 De Louvois J, Gortvai P, Hurley R. Antibiotic treatment of abscesses of the central nervous system. Br Med $\mathcal{f}$ 1977;ii :985-7.

2 Brook I. Aerobic and anaerobic bacterial flora of normal maxillary sinuses. Laryngoscope $1981 ; 91: 372-6$.

${ }^{3}$ Lundberg C, Carenfelt C, Engquist S, Noro CE. Anaerobic bacteria in maxillary sinusitis. Scand $\mathcal{F}$ Infect Dis 1978;suppl 19:74-6.

${ }^{4}$ Brook I, Friedmann E, Rodriguez W, Controni G. Complications of sinusitis in children. Pediatrics $1980 ; 66$ :568-72.

${ }^{5}$ Willis A, Jones P, Reilly S. Management of anaerobic infections: prevention and treatment. Chichester: Research Studies Press (John Wiley \& Son Ltd), $1981: 6,42-3$.

(Accepted 17 November 1983)

Royal National Throat, Nose and Ear Hospital, London WC1X 8DA ANDREW GRACE, MB, BS, registrar

ADRIAN DRAKE-LEE, FRCS, senior registrar

Correspondence to: Dr Andrew Grace.

\section{Hypermagnesaemia and hypophosphataemia after ingestion of magnesium sulphate}

Hypermagnesaemia after ingestion of magnesium sulphate is rare in the absence of intestinal or renal disease. ${ }^{1}$ We report such a case in which the patient made an excellent recovery.

\section{Case report}

A woman aged 25, who had apparently been in good health previously, presented to hospital drowsy and hypothermic. She had been found naked and unconscious early that morning outside her home. Two empty $100 \mathrm{~g}$ bottles of magnesium sulphate (Epsom salts) were found beside her bed. On examination in intensive care she was hypothermic $\left(32^{\circ} \mathrm{C}\right.$ rectally) with considerable pallor and vasoconstriction. Her blood pressure was 120/80 $\mathrm{mm} \mathrm{Hg}$, heart rate 70 beats $/ \mathrm{min}$ and regular, and respiration adequate. She was drowsy, responding only slowly to spoken commands. Her pupils reacted sluggishly to light. Muscle tone was increased, but tendon reflexes were reduced. Focal neurological signs were absent and plantar reflexes equivocal. Electrocardiography showed sinus rhythm with J waves; this is consistent with hypothermia. Full toxicological screening did not detect ethanol or drugs.

Management consisted of gradual warming with blankets and rehydration with warmed intravenous fluids. Over the 24 hours after admission she received 3.51 of fluids containing sodium $140 \mathrm{mmol}(\mathrm{mEq})$, potassium 50 $\mathrm{mmol}(\mathrm{mEq})$, and calcium $15 \mathrm{mmol}(601 \mathrm{mg})$. No phosphate was given. She was alert and orientated and her temperature had returned to normal within eight hours; she was transferred to a general ward the next day.

On admission plasma analysis showed potassium concentration $2 \cdot 8$ mmol/l, urea concentration $3.7 \mathrm{mmol} / 1(22 \mathrm{mg} / 100 \mathrm{ml})$, and creatinine concentration $80 \mu \mathrm{mol} / 1(1.0 \mathrm{mg} / 100 \mathrm{ml})$. The table shows plasma magnesium, calcium, albumin, and phosphate concentrations. Haemoglobin concentration was $17 \cdot 1 \mathrm{~g} / \mathrm{dl}$ and packed cell volume $0 \cdot 52$. Plasma sodium, urea, and creatinine concentrations changed little during the 24 hour period. A spot sample of urine obtained two hours after admission showed magnesium concentra-
Changes in plasma concentrations during treatment

\begin{tabular}{|c|c|c|c|c|c|c|}
\hline & \multirow[b]{2}{*}{$\begin{array}{l}\text { Reference } \\
\text { range }\end{array}$} & \multicolumn{5}{|c|}{ Hours after admission } \\
\hline & & 0 & $\begin{array}{c}2 \mathrm{~h} \\
35 \mathrm{~min}\end{array}$ & $\begin{array}{c}5 \mathrm{~h} \\
15 \mathrm{~min}\end{array}$ & $\begin{array}{c}12 \mathrm{~h} \\
40 \mathrm{~min}\end{array}$ & $\begin{array}{l}22 \mathrm{~h} \\
15 \mathrm{~min}\end{array}$ \\
\hline $\begin{array}{l}\text { Magnesium }(\mathrm{mmol} / \mathrm{l}) \\
\text { Calcium }(\mathrm{mmol} / \mathrm{l}) \\
\text { Albumin }(\mathrm{g} / \mathrm{l})\end{array}$ & $\begin{array}{c}0 \cdot 7-1 \cdot 1 \\
2 \cdot 25-2 \cdot 65 \\
35-45\end{array}$ & $\begin{array}{l}7 \cdot 9 \\
2 \cdot 47 \\
49\end{array}$ & $\begin{array}{l}4 \cdot 7 \\
2 \cdot 07 \\
47\end{array}$ & $\begin{array}{l}2 \cdot 50 \\
1 \cdot 76\end{array}$ & $\begin{array}{l}1 \cdot 18 \\
2 \cdot 02 \\
37\end{array}$ & $\begin{array}{l}0 \cdot 75 \\
2 \cdot 26 \\
36\end{array}$ \\
\hline $\begin{array}{l}\text { Inorganic phosphate } \\
(\mathrm{mmol} / \mathrm{l})\end{array}$ & $0.8-1 \cdot 4$ & 0.39 & 0.20 & 0.75 & 1.07 & $1 \cdot 26$ \\
\hline
\end{tabular}

Conversion: SI to traditional units-Magnesium: $1 \mathrm{mmol} / 1 \approx 2.4 \mathrm{mg} / 100 \mathrm{ml}$. Calcium: $1 \mathrm{mmol} / 1 \approx 4 \mathrm{mg} / 100 \mathrm{ml}$. Inorganic phosphate: $1 \mathrm{mmol} / 1 \approx 3 \cdot 1 \mathrm{mg} / 100 \mathrm{ml}$.

tion $908 \mathrm{mmol} / 1(2210 \mathrm{mg} / 100 \mathrm{ml})$, calcium concentration $16.3 \mathrm{mmol} / 1$ $(65.2 \mathrm{mg} / 100 \mathrm{ml})$, inorganic phosphate concentration $1.0 \mathrm{mmol} / 1(3.1 \mathrm{mg} /$ $100 \mathrm{ml}$ ), and osmolality $1300 \mathrm{mmol}(\mathrm{mosmol}) / \mathrm{kg}$ water.

\section{Comment}

Our patient had presumably taken an overdose of magnesium sulphate. Despite a considerably increased plasma magnesium concentration on admission the cardiovascular effects of hypermagnesaemianamely, hypotension, electrocardiographic changes, and heart blockwere absent. ${ }^{1}$ Normal renal function permitted rapid urinary excretion of magnesium, making an uneventful recovery possible.

Interestingly, the plasma calcium concentration decreased by 0.71 $\mathrm{mmol} / 1(2.8 \mathrm{mg} / 100 \mathrm{ml})$ in the first five and a quarter hours after admission with only a small part of this decrease $(0.16 \mathrm{mmol} / 1(0.6$ $\mathrm{mg} / 100 \mathrm{ml}$ )) being attributable to a concomitant decrease in albumin concentration. Plasma calcium concentration fell despite administration of calcium. Plasma inorganic phosphate concentration also fell initially, reaching a minimum of $0.20 \mathrm{mmol} / 1(0.6 \mathrm{mg} / 100 \mathrm{ml})$ after two and a half hours. The reason for the initial low plasma concentration of inorganic phosphate is not clear. Possibly the sparingly soluble magnesium phosphate was precipitated in tissues. Between two hours 35 minutes and five hours 15 minutes after admission the plasma inorganic phosphate concentration increased by $0.55 \mathrm{mmol} / 1$ (1.7 $\mathrm{mg} / 100 \mathrm{ml}$ ) even though no phosphate was given.

Hypermagnesaemia may cause hypocalcaemia. This effect may possibly be mediated by decreased secretion of parathyroid hormone ${ }^{2}$ and responsiveness of end organs. ${ }^{3}$ An effect of hypermagnesaemia on plasma concentrations of inorganic phosphate has not, however, been described before. The increase in plasma inorganic phosphate concentration from a minimum of $0.2 \mathrm{mmol} / 1(0.6 \mathrm{mg} / 100 \mathrm{ml})$ may be explained by two mechanisms. Firstly, decreased parathyroid hormone activity would increase renal tubular absorption and reduce urinary excretion of phosphate. The low phosphate concentration in the spot sample of urine supported this possibility. Secondly, phosphate may have become mobilised from the precipitated magnesium phosphate as plasma magnesium concentrations fell rapidly to normal.

Our patient had severe hypermagnesaemia resulting presumably from ingestion of magnesium sulphate. Respiratory and cardiovascular complications were absent. The changes in plasma calcium and phosphate concentrations seen in this patient provide further evidence for the sugggestion that hypermagnesaemia causes decreased parathyroid hormone activity.

1 Mordes JP, Wacker WEC. Excess magnesium. Pharmacol Rev 1977;29: 273-300.

2 Massry SG, Coburn JW, Kleeman CR. Evidence for suppression of parathyroid gland activity by hypermagnesemia. F Clin Invest 1970;49:161929.

${ }^{3}$ Slatopolsky E, Mercado A, Morrison A, Yates J, Klahr S. Inhibitory effects of hypermagnesemia on the renal action of parathyroid hormone. $\mathcal{F}$ Clin Invest $1976 ; 58: 1273-9$.

(Accepted 10 November 1983)

Department of Clinical Biochemistry, University of Western Australia, Perth, Australia 6009

P GARCIA-WEBB, MD, FRCPA, senior lecturer

C BHAGAT, MD, FRCPA, senior registrar

Intensive Care Unit, Sir Charles Gairdner Hospital, Perth, Australia 6009

T OH, FFARCS, FFARACS, director

G HART, MB, BS, registrar

W THOMPSON, MB, FFARACS, staff specialist

Correspondence to : Dr P Garcia-Webb. 